\title{
Growth Failure in Cholestatic Rats: The Effect of Malnutrition on Insulin-Like Growth Factor $\mathbf{I}^{\mathbf{1}}$
}

\author{
BRUNO P. DESCOS, SUSAN A. BERRY, HARVEY L. SHARP, CYNTHIA R. GROSS, \\ SALLY A. WEISDORF, AND ORA HIRSCH PESCOVITZ ${ }^{2}$ \\ Departments of Pediatrics [B.P.D., S.A.B., H.L.S., S.A.W., O.H.P.] and Pharmacy Practice [C.R. G.], University \\ of Minnesota, Minneapolis, Minnesota 55455
}

\begin{abstract}
Low IGF-I levels are found in patients with chronic liver disease, but it is not known whether these reductions in IGF-I are secondary to hepatic dysfunction or to malnutrition. To determine whether malnutrition associated with hepatic dysfunction causes the decrease in these levels, serum and liver IGF-I concentrations and liver IGF-I mRNA content were compared in three groups of Sprague-Dawley rats: 15 rats underwent bile duct obstruction; 10 rats were sham-operated and pair-fed with operated rats to control for nutritional status; and 12 rats were sham-operated controls fed ad libitum. In addition, IGF-I peptide and mRNA were compared with food intake, crude nitrogen balance, total wt gain, tail length increase and leg muscle wt. All the parameters were lower in cholestatic and nutritionally deprived animals than in control animals $(p<0.001)$. There was no difference in serum and hepatic IGF-I and liver IGF-I mRNA values between the 10 cholestatic and pair-fed animals, despite lower crude nitrogen balance, tail length gains, and leg muscle wt in the bile duct-obstructed animals. These studies suggest that in chronic bile duct obstruction, the low serum and hepatic IGF-I levels are primarily due to decreased food intake and appear unrelated to cholestatic liver disease itself. However, factors in addition to suboptimal nutrition and decreased IGF-I levels must also contribute to cholestasisinduced growth failure. (Pediatr Res 26: 410-414, 1989)
\end{abstract}

\section{Abbreviations}

OP, operated (bile duct obstruction)

PF, pair-fed

CON, control

HYPOX, hypophysectomized

GH, growth hormone

ANOVA, analysis of variance

Most children with chronic cholestatic liver disease suffer from malnutrition and growth failure (1-3). It has been suspected that this poor growth is related to depressed somatomedin levels because the liver is a major source of circulating somatomedins

Received February 14, 1989; accepted July 10, 1989.

Correspondence and reprint requests Susan A. Berry, M.D., Department of Pediatrics, Box 75 UMHC, University of Minnesota-Variety Club Childrens' Hospital, Harvard St. at E. River Rd., Minneapolis, MN 55455.

Supported in part by grants from the National Institutes of Health (R29DK38480, S.A.B.; N01DK62274 and P30DK34931, H.L.S.); and the Hospices Civile de Lyon, NATO, Foundation pour la Recherche Medicale, and the Phillipe Foundation (B.P.D.).

${ }_{1}^{1}$ Presented in part to the American College of Nutrition, 1988 Annual Meeting.

${ }_{2}^{2}$ Present address Department of Pediatrics, Indiana University Medical Center, Indianapolis, IN 46223 .
(4), and either circulating or local IGF-I is believed to mediate most of the growth-promoting actions of $\mathrm{GH}$ on peripheral tissues (5). Reductions in somatomedins measured by a variety of methods have been observed in studies on adults with chronic liver disease. Wu et al. (6) initially demonstrated depressed somatomedins (measured as sulfation factor) in adults with cirrhosis, and this finding was confirmed in additional studies using radioreceptor assays $(7)$ and RIA $(8,9)$. Unfortunately, the role of malnutrition in these patients was not considered. Malnutrition alone also results in depression of somatomedins (measured as sulfation factor) (10-12). Deficient IGF-I production might thus contribute to the growth failure observed in children with chronic cholestatic liver disease, either because of intrinsic liver dysfunction or malnutrition, or both. In addition, $\mathrm{GH}$ levels are elevated both in patients with chronic liver disease (13) and with malnutrition $(11,12)$. It has been proposed that malnutrition, in the absence of hepatic failure, results in a GH postreceptor defect $(14,15)$. Preliminary studies in children also suggest that short stature in chronic liver failure may be due to a relative $\mathrm{GH}$ resistance and further that this may be independent of nutritional status (16). Thus, abnormal IGF-I levels associated with chronic liver disease could be the result of decreased hepatic synthesis of IGF-I or be the direct result of a defect in response to $\mathrm{GH}$ caused by either malnutrition or intrinsic hepatic dysfunction.

The following studies were designed to determine the effects of liver disease and malnutrition on growth and IGF-I production. We used a model of bile duct obstruction to induce cholestatic liver disease and growth failure in young rats. To assess the effects of nutrition, we pair-fed the cholestatic animals with sham-operated rats. Serum IGF-I levels, liver IGF-I content and liver IGF-I mRNA were assessed in all groups.

\section{MATERIALS AND METHODS}

Animals. Prior approval for all procedures was obtained from the institutional committee for the use of animals in research (Research Animal Resources, University of Minnesota, MN). Three groups of weanling Sprague Dawley rats (Bio-Laboratory, St. Paul, MN) were studied at $21 \mathrm{~d}$ of age: 15 rats (eight males, seven females) OP; 10 rats (five males, five females) were shamoperated and PF with OP rats to control for the contribution of nutritional intake; 12 rats (six males, six females) were shamoperated CON and were fed ad libitum. In brief, the surgery for the bile duct obstruction included three ligatures tied securely around the common bile duct. The bile duct was transected between the two sutures most distal from the liver. Shamoperated animals underwent an identical procedure without ligation and transection. The animals were returned to the cage with litter mates for $1 \mathrm{~d}$ and then roomed individually in metabolic cages. Rats were fed with Purina Rodent Laboratory Chow 5001 (St. Louis, MO). Each PF rat was PF with another OP rat. 
The amount of food ingested by the OP rats was measured daily and the same amount of food was given to the corresponding PF rats unless the $\mathrm{PF}$ rat was bigger. When the $\mathrm{PF}$ rat was bigger than the OP, the same amount calculated per gram of body wt was given. Total food intake was recorded and urine collected for each animal. Wt and tail length measurements were recorded on the day of surgery and at time of sacrifice. The animals were killed at $41 \mathrm{~d}$ of age by exsanguination after sodium pentobarbital anesthesia. Serum was frozen for bilirubin, albumin, and IGF-I assays. The liver was perfused with chilled saline until it became pale to eliminate peripheral blood IGF-I contamination of liver IGF-I. After weighing, a portion was reserved for histologic examination. The major portion was frozen in liquid nitrogen and stored at $-70^{\circ} \mathrm{C}$ for IGF-I peptide and IGF-I mRNA measurements. Aliquots were saved for determination of total protein (17). Gastrocnemius muscle was removed and weighed as another parameter of growth. The same parameters were also determined in an additional 10 HYPOX rats (five males, five females) aged $41 \pm 3 \mathrm{~d}$ (Taconic Laboratories, Germantown, NY). Hypophysectomy was performed by the supplier at $28 \pm 3$ d of age.

Serum IGF-I. Serum IGF-I levels were assayed in duplicate using a RIA kit purchased from Nichols Institute Diagnostics (San Juan Capristano, CA) and a polyclonal antibody which recognizes rat IGF-I (gift of Dr. L. Underwood, University of North Carolina, Chapel Hill, NC). Serum samples were subjected to acid-ethanol extraction before assay to free IGF-I from binding proteins as described (18). The intraassay coefficient of variation was $3.42 \%$. The interassay coefficient of variation of an adult rat pool was $11.4 \%$. When IGF-I in the form of extracted adult rat pool serum was added to the samples, recovery was $101-131 \%$.

Liver IGF-I. Acetic acid extraction of liver was performed as described (19). Extracts were frozen at $-20^{\circ} \mathrm{C}$ for IGF-I RIA (within $6 \mathrm{wk}$ ). All studies were performed on liver perfused with chilled saline to minimize the contribution of circulating IGF-I on the measurement of tissue levels, as we found that in four (41 d old) rats, saline perfusion of liver decreased the IGF-I content by $12.6 \%$ in comparison with values obtained in three rats of the same age without liver perfusion. This estimate of peripheral blood contribution to liver IGF-I was similar to the $17 \pm 2.4 \%$ estimate of D'Ercole et al. (20) calculated by measuring liver hemoglobin content. Recovery of IGF-I in the form of extracted adult rat pool serum added to liver extracts averaged 62.8-65.8\%.

Liver IGF-I $m R N A$. Dot blot hybridization. Liver IGF-I mRNA was measured after guanidine- $\mathrm{HCl}$ extraction of total hepatic RNA (21). Total IGF-I mRNA was measured by dotblot hybridization (21) with an IGF-I cDNA insert. The cDNA probe used in this study was a $2.2-\mathrm{kb}$ fragment obtained by screening a $\lambda$ gt 11 adult rat liver cDNA library (Dr. H. Towle, Minneapolis, MN) with a human IGF-I cDNA (Dr. K. Gabbay, Houston, TX). The identity of the probe was established by cDNA sequencing with comparison of these data to published sequences for this gene (data not shown). Sequence analysis confirmed that this probe is like the IGF-IA cDNA reported by Roberts et al. (22). The probe was labeled using the oligo labeling kit from Pharmacia (Piscataway, NJ). Typical specific activities of labeled cDNA were 5-9 $\times 10^{8} / \mu \mathrm{g}$ DNA. After hybridization, the dot-blots were washed four times for $10 \mathrm{~min}$ in $2 \times \mathrm{SSC}(1$ $\times \mathrm{SSC}=0.15 \mathrm{M} \mathrm{NaCl}$ and $0.015 \mathrm{M} \mathrm{Na}$ citrate, $\mathrm{pH} 7.0), 0.1 \%$ $\mathrm{SDS}$ at $25^{\circ} \mathrm{C}$ and three times in $0.2 \times \mathrm{SSC}, 0.1 \% \mathrm{SDS}$ at $60^{\circ} \mathrm{C}$ twice for $45 \mathrm{~min}$ and once for $30 \mathrm{~min}$. The papers were blotted, and exposed to Kodak XAR-5 x-ray film (Eastman Kodak, Rochester, NY) for autoradiography, typically overnight at $23^{\circ} \mathrm{C}$. The intensity of the signal was determined by videodensitometry (23), and expressed as a percentage of IGF-I mRNA observed in adult rat pooled RNA. Samples were blotted at four concentrations and the $\mathrm{OD} / \mu \mathrm{g}$ RNA was determined by linear regression. For all samples, $r$ for the regression of concentration versus intensity was more than 0.98 .

Northern gel analysis. Liver IGF-I mRNA species were ex- amined using Northern gels under formaldehyde denaturing conditions (24). The gels were electrotransferred in $0.75 \times \mathrm{TAE}$ $(10 \times$ TAE: $100 \mathrm{mM}$ Tris Base, $50 \mathrm{mM}$ ammonium acetate, 5 mM EDTA) using a Transblot apparatus (Bio-Rad Laboratories, Richmond, CA) on Zetabind (Cuno, Inc., Meriden, CT) at $80 \mathrm{~V}$ for $5 \mathrm{~h}$. Filters were air-dried and baked for $2 \mathrm{~h}$ at $80^{\circ} \mathrm{C}$ under vacuum. Hybridization was performed by the above procedure except the hybridization solution contained $2 \times$ Denhardt's solution, $0.1 \% \mathrm{SDS}$, and $0.1 \mathrm{mg} / \mathrm{mL}$ sheared salmon sperm DNA.

Albumin and Total Bilirubin. Serum albumin was measured using the colorimetric methodology of the Kodak Ektachem Clinical Chemistry Slides (ALB) (Eastman Kodak Company, Rochester, NY) by the bromcresol green dye.

Total serum bilirubin was measured using colorimetric methodology of the Kodak Ektachem Clinical Chemistry Slides (TBIL) (Eastman Kodak Company, Rochester, NY) by the diazonomium salt.

Urine Nitrogen and Estimated Nitrogen Balance. Urine from each animal was pooled and total urine nitrogen was measured using chemiluminescent total nitrogen analysis (25). Estimated nitrogen balance was calculated from the second postoperative day until death by subtracting urine nitrogen excretion from intake.

Histology. A portion of the liver was fixed in buffered formalin and processed for histologic examination. Hematoxylin and eosin stained microscopic sections were evaluated in a blinded fashion by one of the authors (H.L.S.).

Statistical Analysis. Mean measurements were compared across the three study groups using ANOVA. Where an overall difference among group means was found, the Scheffé method for multiple comparisons was used to test for the differences between OP and CON groups, between $\mathrm{PF}$ and CON groups, and between HYPOX and the other groups. Comparisons between measurements for the subset of 10 pair-rats of the OP and PF groups were performed using Student's $t$ test for paired values. Pearson product-moment correlation coefficient was used to assess the relationship between serum IGF-I and bilirubin in OP rats.

\section{RESULTS}

All bile duct-ligated rats were clinically jaundiced at the time of death. Bilirubin was greater than 42.75 in all OP rats (mean $\pm \mathrm{SD}: 68.23 \pm 21.72 \mu \mathrm{M}$ ), and was normal in the other rats (PF: $3.08 \pm 2.05 \mu \mathrm{M}, \mathrm{CON}: 3.25 \pm 2.39 \mu \mathrm{M}$ ). In OP rats, histologic examination showed ductular cholestasis, bile duct proliferation, and intermittent bridging fibrosis between portal tracts. In PF rats, the liver was normal. In some $\mathrm{CON}$ rats, hepatocytes were vacuolated with microvesicular fat. The successful implementation of the PF was demonstrated by the similarity of the total food intake between the subset of matched OP and PF animals and the significant differences between these groups and the CON group (Fig. 1). Serum albumin concentrations were not significantly different among the three groups (CON: $27.0 \pm 2.6$, OP: $29.1 \pm 5.2$, PF: $30.2 \pm 5.1 \mathrm{~g} / \mathrm{L})$. However, estimated nitrogen balance was higher in CON than in either OP or PF rats $(p<$ $0.001)$ and higher in PF than in OP rats $(p<0.05)$ (Fig. 1).

Changes in physical parameters of growth are demonstrated in Figure 2. Significant differences $(p<0.001)$ were found in wt gain, tail length increase, leg muscle wt, and liver wt when expressed as g liver/g body wt. Wt gain was higher in CON than in OP or PF rats $(p<0.001)$. The higher wt gain in 10 matched OP than in PF rats $(p<0.05)$ was attributed to significant ascites and increased liver wt. Tail length increase was greater in CON than in OP or PF rats $(p<0.001)$. However, tail length increase was higher in PF than in OP rats $(p<0.001)$. Leg muscle wt was higher in CON than in OP or in PF rats $(p<0.001)$, and in $\mathrm{PF}$ than in OP rats $(p<0.01)$. Liver wt when expressed as percentage of $\mathrm{g} / \mathrm{g}$ body wt was similar in $\mathrm{CON}$ and in PF rats 

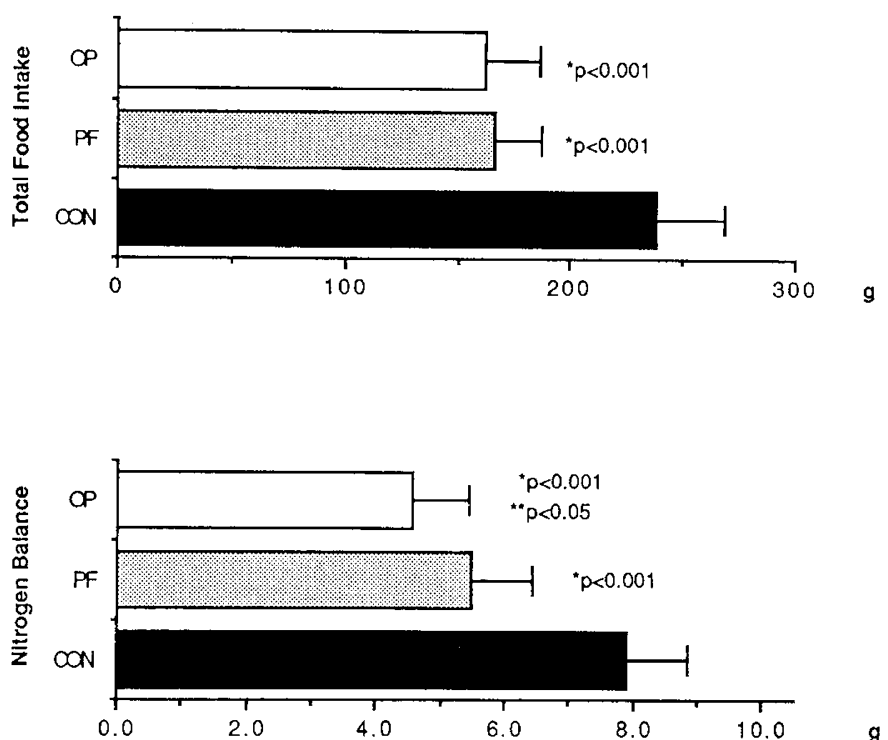

Fig. 1. Total food intake (g) and estimated nitrogen balance $(\mathrm{g})$ in 12 $\mathrm{CON}, 10 \mathrm{PF}$, and $15 \mathrm{OP}$ rats. * statistical comparison of $\mathrm{PF}$ or $\mathrm{OP}$ versus $\mathrm{CON}$; ** statistical comparison of OP versus PF. Values shown are means $\pm \mathrm{SD}$. The differences in the groups for estimated nitrogen balance were significant $\left(p<0.01, \mathrm{~F}_{2,34}=45.49\right)$.
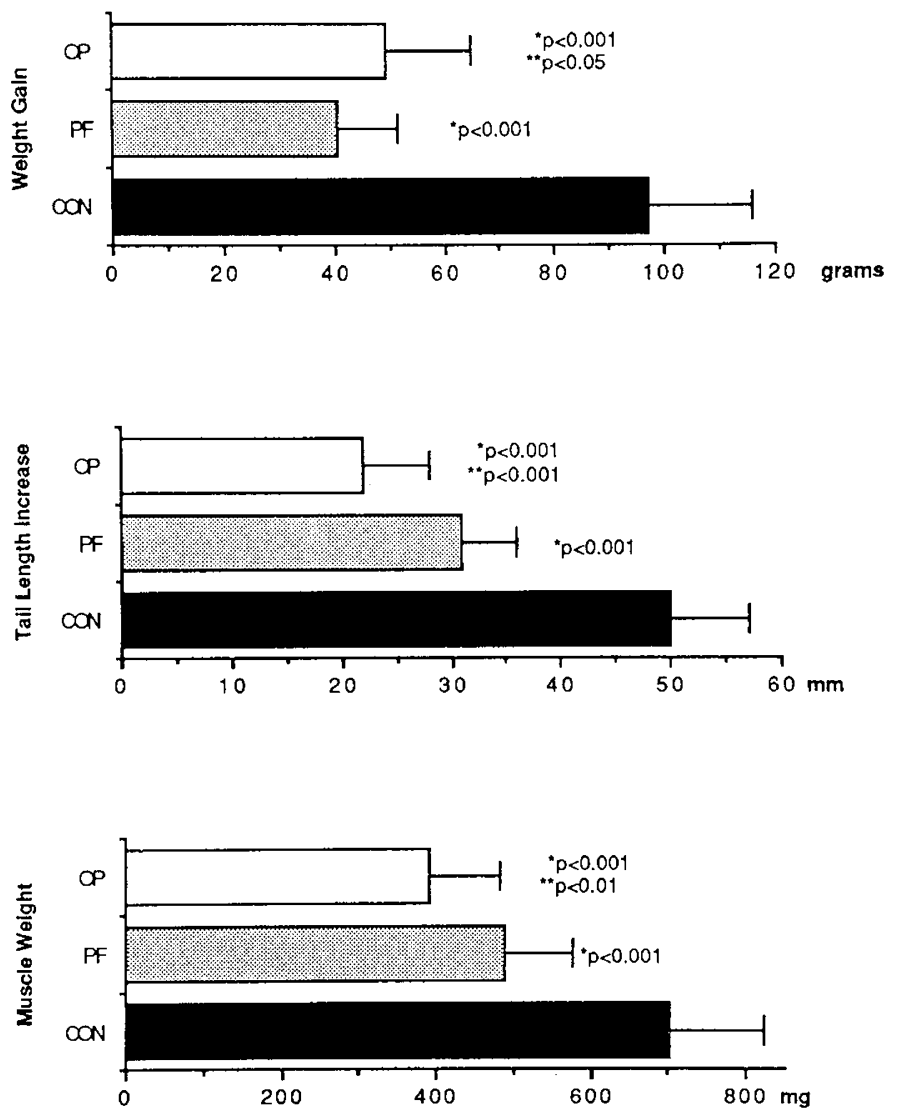

Fig. 2. Wt gain (g), tail length increase $(\mathrm{mm})$, leg muscle wt $(\mathrm{mg})$ in 12 sham-operated CON rats fed ad libitum, 10 sham-operated and PF rats, and $15 \mathrm{OP}$ rats $(O P)$. $^{*}$ statistical comparison of $\mathrm{PF}$ or $\mathrm{OP}$ versus $\mathrm{CON} ;{ }^{* *}$ statistical comparison of OP versus PF. Values shown are means $\pm \mathrm{SD}$. Significant differences $(p<0.001)$ are found in wt gain $\left(\mathrm{F}_{2,34}=\right.$ $43.54)$, tail length increase $\left(F_{2,34}=66.72\right)$, and leg muscle wt $\left(F_{2,34}=\right.$ 32.24).
$(4.7 \pm 0.6$ versus $4.5 \pm 0.9 \% \mathrm{~g} / \mathrm{g})$ and higher in OP rats $(7.7 \pm$ $0.8 \% \mathrm{~g} / \mathrm{g}, p<0.001)$.

Serum and tissue IGF-I values by RIA and tissue IGF-I mRNA measurements are summarized in Figure 3. Serum IGF-I levels were 3.5 times higher in CON rats than either OP or PF rats $(p$ $<0.001$ ), but not different between PF and OP rats. In 10 HYPOX rats, serum IGF-I concentrations were significantly lower than in all the other groups $(p<0.001)$. No correlation was found between serum IGF-I levels and bilirubin concentrations in the OP rats. Liver IGF-I levels, expressed per $g$ of liver protein, were 2.9 times higher in CON compared to OP rats and 2.1 times those observed in PF animals ( $p<0.001$ for both), and not different between PF and OP rats. In 10 HYPOX rats, liver IGF-I concentrations per $\mathrm{g}$ of protein were again significantly lower than in the other groups $(p<0.001)$. Liver IGF-I mRNA levels were essentially twice as high in CON animals compared to either OP or PF rats (1.8- and 2.1 -fold changes, respectively), but not different between $\mathrm{PF}$ and $\mathrm{OP}$ rats. In HYPOX rats, the autoradiogram signal was insufficient for quantitation. Changes in tissue IGF-I levels measured by RIA closely paralleled changes observed in IGF-I mRNA in terms of fold change.

Hybridization of IGF-I cDNA containing sequences common to all IGF-I mRNA to Northern blots of RNA from OP, PF, and $\mathrm{CON}$ rat liver demonstrated the presence of the major species of hepatic IGF-I mRNA [0.8-1.2 kb, $1.7 \mathrm{~kb}$, and $7.5 \mathrm{~kb}(26)]$ in all three groups of rats (Fig. 4). Shown are representative lanes from one gel. Bile duct ligation and malnutrition did not alter the distribution of the RNA hybridizing to these major bands, but resulted in a uniform diminution of all hybridizing RNA species.

\section{DISCUSSION}

Children with cholestatic disease, especially with extrahepatic biliary atresia, constitute the largest group of pediatric patients requiring liver transplantation, as this is the only therapy available for the end stage of this disease. Improvement of nutritional status is associated with increased survival although normal linear growth is not achieved in all patients even after liver transplantation and improved nutrition $(2,3)$. In our model of cholestasis in juvenile rats, we found decreased levels of serum IGF-I. However, we found no correlation between serum IGF-I levels and the degree of cholestasis as judged by serum bilirubin levels. Liver IGF-I content and serum IGF-I levels were decreased to a similar degree suggesting impaired IGF-I synthesis rather than decreased release of liver IGF-I. The low levels of liver IGFI mRNA found in cholestatic rats are consistent with an IGF-I synthesis defect, and suggest an abnormality at the pretranslational level. Serum levels of IGF-I were four times higher in control than in bile duct-obstructed or malnourished animals, whereas liver IGF-I mRNA levels were 2-fold different. Although this fold difference is small, it may also reflect posttranslational modulation of IGF-I serum levels, or a difference in the metabolic clearance rate of the circulating peptide. Low circulating IGF-I levels may be responsible for the high $\mathrm{GH}$ levels observed in chronic liver disease (12) because of a decrease in the negative feedback inhibition of GH secretion (27).

This study was performed to evaluate if the role of nutrition could be dissociated from the role of other factors in liver diseaseassociated growth failure. Although low IGF-I levels were found in animals with cholestasis, the levels were comparable to similarly malnourished animals that did not have impaired liver function. Thus, IGF-I levels are more likely to be related to decreased food intake than to cholestatic liver disease. Malabsorption is well documented in chronic liver disease especially in cholestasis (28). Metabolism of all three macronutrients (fat, protein, and carbohydrate) is affected by hepatic dysfunction (29). The association between malnutrition and reduced IGF-I levels has been reported previously in rats as a decrease in 

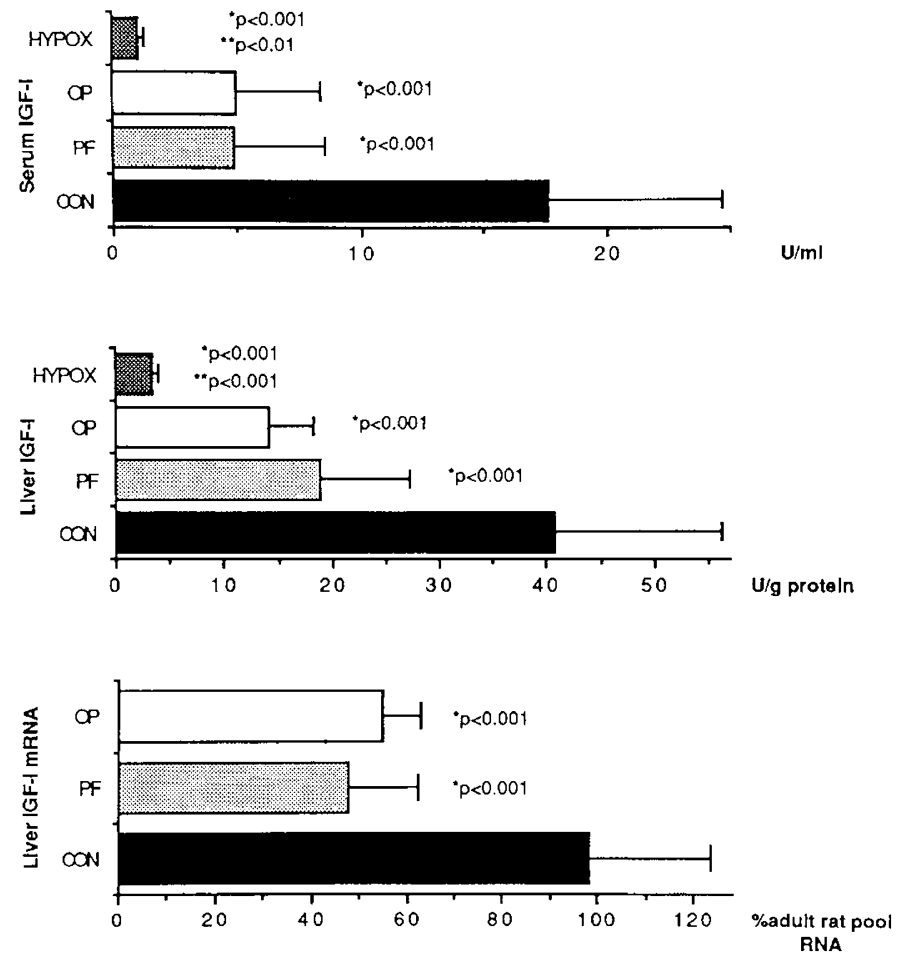

Fig. 3. Serum and liver IGF-I concentrations and hepatic IGF-I mRNA in 12 CON, 10 PF, 15 OP rats, and 10 HYPOX rats. Liver IGFI mRNA content is expressed as a percentage of IGF-I mRNA observed in adult rat pooled RNA. * statistical comparison of PF or OP versus CON; ** statistical comparison of HYPOX versus OP, PF, CON. Values shown are means $\pm \mathrm{SD}$. Significant differences were present for both serum $\left(F_{2,34}=26.74\right)$ and liver $\left(F_{2,34}=23.88\right)$ IGF-I by RIA and for liver IGF-I mRNA measurements $\left(\mathrm{F}_{2,34}=30.36\right)$.

somatomedin bioactivity (30). Low somatomedin levels noted in children with protein-calorie malnutrition were improved by refeeding $(10,11)$. Normalization of somatomedin levels has been documented during refeeding in malnourished rat pups (15), fasted adult rats (31), human volunteers (32), and in chronic diseases associated with malnutrition (33). However, a direct relationship between IGF-I levels and growth velocity is not consistently demonstrated.

Although both the cholestatic and sham-operated, PF animals were clearly undernourished, albumin concentrations were not significantly different when compared to control rats fed ad libitum. This supports the hypothesis of others that a reduction in circulating IGF-I levels is a more sensitive indicator of malnutrition than traditional indices, such as serum albumin or transferrin (34).

Growth failure, as measured by tail length and muscle mass changes, was greater in cholestatic rats than in those with malnutrition alone despite similar decreases in IGF-I. Thus, growth failure in chronic liver disease might not be explained solely by poor nutritional intake and low serum IGF-I levels. The lower nitrogen balance found in cholestatic rats was comparable to sham operated animals of equal nutritional status, suggesting either less efficient utilization of nutrients or increased catabolism. Patients with liver disease may have decreased cortisol clearance $(35)$ that might contribute to poor muscle mass and low nitrogen balance. Somatomedin inhibitors may be produced by liver and are reportedly elevated in fasted animals $(36,37)$ and may decrease after improved nutrition. Somatomedin inhibitor levels have not been reported in chronic liver disease but might contribute to the growth failure.

In conclusion, the low IGF-I levels observed in chronic liver disease are most likely a function of inadequate nutrition. Un-

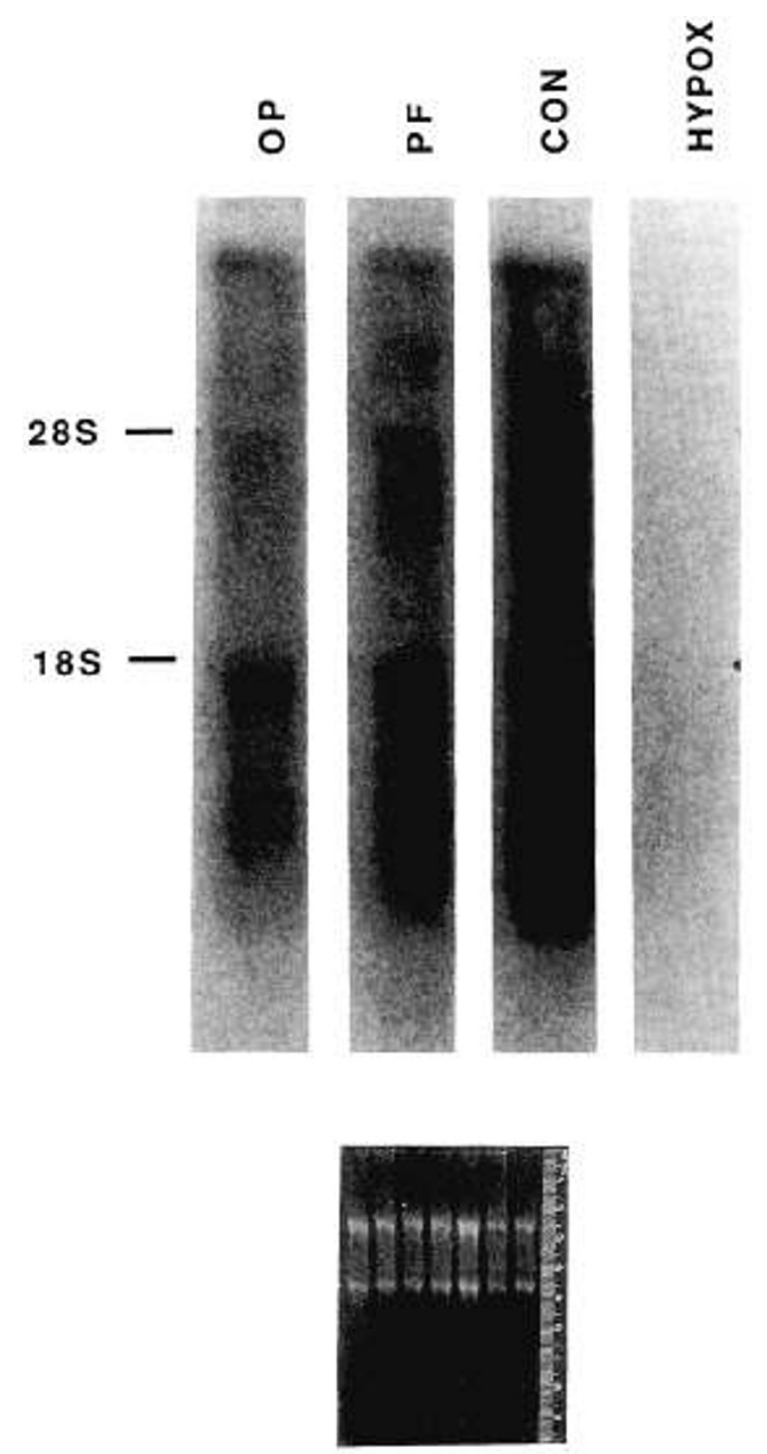

Fig. 4. Northern blot of total RNA extracted from representative OP, PF, CON, and HYPOX rats. Size markers are 18 and 28 S RNA species. Shown as an inset is the ethidium bromide stained gel from which these samples were transferred, demonstrating approximately equal intensities of major ribosomal species for all lanes. Lanes shown in the figure above are $1(\mathrm{OP}), 3(\mathrm{PF}), 5(\mathrm{CON})$, and 7 (HYPOX). OP and PF rats have lower levels of all RNA species hybridizing to this IGF-I cDNA when compared to CON. No signal was observed in RNA from HYPOX animals at this exposure. Similar results for each experimental group were seen on additional gels, and on other lanes on this gel (not shown).

known factors, in addition to decreased IGF-I and inadequate nutrition, must also contribute to the growth failure observed in chronic liver disease.

Acknowledgments. The authors thank Dr. Kaz Paradis for his valuable contributions to the success of this project, and Dr. Eric Wong for performing the sequence analysis on the rat IGF-I cDNA. Excellent technical assistance was provided by Kathy Cleary, Mary Bundy, and Bill Radmer.

\section{REFERENCES}

1. Burgess DB, Martin HP, Lilly JR 1982 The developmental status of children undergoing the Kasai procedure for biliary atresia. Pediatrics 70:624-629

2. Urbach AH, Gartner JC, Malatack JJ, Zitelli BJ, Iwatsuki S, Shaw BW, Starzl TE 1987 Linear growth following pediatric liver transplantation. Am J Dis Child 141:547-549 
3. Spolidoro JV, Berquist WE, Pehlivanoglu E, Busuttil R, Saluski I, Vargas J, Ament ME 1988 Growth acceleration in children after orthotopic liver transplantation. J Pediatr 112:41-44

4. Daughaday WH, Phillips LS, Mueller MC 1976 The effects of insulin and growth hormone on release of somatomedin by the rat liver. Endocrinology 98:1214-1219

5. Froesch ER, Schmid C, Schwander J, Zapf J 1985 Actions of insulin-like growth factors. Annu Rev Physiol 47:443-467

6. Wu A, Grant DB, Hambley J, Levi AJ 1974 Reduced serum somatomedin activity in patients with chronic liver disease. Clin Sci Mol Med 47:359-366

7. Minuto F, Barreca A, Del Monte P, Buffa C, Bevevino R, Montale F, Torre $\mathrm{G}$, Giordano $\mathrm{G} 1984$ In vivo and in vitro effect of liver on somatomedin generation. Horm Metab Res 16:663-666

8. Wu J-C, Daughaday WH, Lee S-D, Hsiao TS, Chou C-K, Lin H-D, Tsai Y-T, Chiang BN 1988 Radioimmunoassay of serum IGF-I and IGF-II in patients with chronic liver diseases and hepatocellular carcinoma with or without hypoglycemia. J Lab Clin Med 112:589-594

9. Zapf J, Morell B, Walter H, Laron Z, Froesch ER 1980 Serum levels of insulinlike growth factor (IGF) and its carrier protein in various metabolic disorders. Acta Endocrinol 95:505-517

10. Grant DB, Hambley J, Becker D, Pimstone BL 1973 Reduced sulfation factor in undernourished children. Arch Dis Child 48:596-600

11. Hintz RL, Suskind R, Amatayakul K, Thanangkul O, Olson R 1978 Plasma somatomedin and growth hormone values in children with protein-calorie malnutrition. J Pediatr 92:153-156

12. Mohan PS, Rao KSJ 1979 Plasma somatomedin activity in protein-calorie malnutrition. Arch Dis Child 54:62-64

13. Cameron DP, Burger HG, Catt KJ, Gordon E, Watts J McK 1972 Metabolic clearance of human growth hormone in patients with hepatic and renal failure, and the isolated perfused pig liver. Metabolism 21:895-904

14. Maes M, Amand Y, Underwood LE, Maiter D, Ketelslegers JM 1988 Decreased serum insulin-like growth factor I response to growth hormone in hypophysectomized rats fed a low protein diet: evidence for a postreceptor defect. Acta Endocrinol (Copenh) 117:320-326

15. Maes M, Underwood LE, Gérard G, Ketelslegers JM 1984 Relationship between plasma somatomedin-C and liver somatogenic binding sites in neonatal rats during malnutrition and after short and long term refeeding. Endocrinology 115:786-792

16. Bucuvalas JC, Cutfield, W, Chernausek SD, Lonow JA, Campaign B, Heubi JE 1989 Short stature due to chronic liver disease is accompanied by growth hormone resistance independent of nutritional status. Pediatr Res 25:109A(abstr)

17. Lowry OH, Rosebrough NJ, Farr AL, Randall RJ 1951 Protein measurement with the Folin phenol reagent. J Biol Chem 193:265-275

18. Daughaday WH, Mariz IK, Blethen SL 1980 Inhibition of access of bound somatomedin to membrane receptor and immunobinding sites: a comparison of radioreceptor and radioimmunoassay of somatomedin in native and acid-ethanol-extracted serum. J Clin Endocrinol Metab 51:781-788

19. D'Ercole AJ, Underwood LE 1987 Estimation of tissue concentrations of somatomedin C/insulin-like growth factor I. Methods Enzymol 146:227233

20. D'Ercole AJ, Stiles AD, Underwood LE 1984 Tissue concentrations of soma- tomedin C: Further evidence for multiple sites of synthesis and paracrine or autocrine mechanisms of action. Proc Natl Acad Sci USA 81:935-939

21. Berry SA, Seelig S 1986 Differential endocrine regulation of $\alpha 2$ u-globulin messenger ribonucleic acid activity: effect of age at hypophysectomy. Endocrinology 119:600-605

22. Roberts CT, Lasky SR, Lowe WL, Seaman WT, LeRoith D 1987 Molecular cloning of rat insulin-like growth factor I complementary deoxyribonucleic acids: differential messenger ribonucleic acid processing and regulation by growth hormone in extrahepatic tissues. Molec Endocrinol 1:243-248

23. Mariash CN, Seelig S, Oppenheimer JH 1982 A rapid, inexpensive, quantitative technique for the analysis of two-dimensional electrophoretograms. Anal Biochem 121:388-394

24. Lehrach H, Diamont D, Wozney JM, Boedtker H 1977 RNA molecular weight determinations by gel electrophoresis under denaturing conditions, a critical reexamination. Biochemistry 16:4743-4751

25. Ward MWN, Owens CWI, Rennie MJ 1980 Nitrogen estimation in biologic samples by use of chemiluminescence. Clin Chem 26:1336-1339

26. Shimatsu A, Rotwein P 1987 Mosaic evolution of insulin-like growth factors: organization, sequence, and expression of the rat insulin-like growth factor I gene. J Biol Chem 262:7894-7900

27. Abe H, Molitch M, Van Wyk JJ, Underwood LE 1983 Human growth hormone and somatomedin-C suppress the spontaneous release of growth hormone in unanesthetized rats. Endocrinology 113:1319-1324

28. Glasgow JFT, Hamilton JR, Sass-Kortsak A 1973 Fat absorption in congenital obstructive liver disease. Arch Dis Child 48:601-607

29. Schersten T 1979 Metabolic differences between hepatitis and cholestasis in human liver. In: Popper H, Shaffer F (eds) Progress in Liver Diseases. Grune and Stratton, New York, pp 133-150

30. Takano K, Hizuka N, Kawai K, Shizume K 1978 Effect of growth hormone and nutrition on the level of somatomedin $A$ in the rat. Acta Endocrinol $87: 416-418$

31. Phillips LS, Orawski AT, Belosky DC 1978 Somatomedin and nutrition. IV. Regulation of somatomedin activity and growth cartilage activity by quantity and composition of diet in rats. Endocrinology 103:121-127

32. Clemmons DR, Klibansky A, Underwood LE, McArthur JW, Ridgway EC, Beitins IZ, Van Wyk JJ 1981 Reduction of plasma immunoreactive somatomedin-C during fasting in humans. J Clin Endocrinol Metab 53:12471250

33. Kirschner BS, Sutton MM 1986 Somatomedin-C levels in growth-impaired children and adolescents with chronic inflammatory bowel disease. Gastroenterology 91:830-836

34. Unterman TG, Vaquez RM, Slas AJ, Martyn PA, Phillips LS 1985 Nutrition and somatomedin: XIII. Usefulness of somatomedin-C in nutritional assessment. Am J Med 78:228-234

35. McCann VJ, Fullon TT 1975 Cortisol metabolism in chronic liver disease. J Clin Endocrinol Metab 40:1038-1044

36. Vassilopoulou-Sellin R, Phillips LS, Reichard LA 1980 Nutrition and soma tomedin. VII Regulation of somatomedin activity by the perfused rat liver. Endocrinology 106:260-267

37. Vassilopoulou-Sellin R, Oyedeji CO, Samaan NA 1984 Extraction of cartilage sulfation inhibitors and somatomedins from rat liver. Endocrinology 1 14:576-581 